\title{
PROSPEK PEMANFAATAN BIOPESTISIDA BAKTERI ENTOMOPATOGENIK ISOLAT LOKAL SEBAGAI AGEN PENGENDALI HAYATI HAMA TANAMAN SAYURAN
}

\section{UTILIZATION PROSPECT OF BIOPESTICIDE OF ENTOMOPATHOGENIC BACTERIA FROM LOCAL ISOLATE AS BIOLOGICAL CONTROL AGENT ON VEGETABLE INSECT PESTS}

\author{
Christina. L. Salaki, Dantje Tarore, dan Guntur Manengkey*)
}

*)Jurusan Hama dan Penyakit Tumbuhan, Fakultas Pertanian, Unsrat Manado 95115

\begin{abstract}
The utilization efforts of entomopathogenic bacteria as an insecticide is still being developed. One of the potential pathogen, which is developed as a source of insecticide is Bacillus spp. The study aims to determine the level of pathogenicity, and get the pathogenity spectrum isolates in the high virulences against the pests of vegetable crops to be used as a biopesticide candidates. Testing the power to kill larvae isolates of Bacillus thuringiensis against Crocidolomia binotalis, Plutella xylostella and Spodoptera litura was performed by the Method of Ohba and Aizawa. The results showed that, of 21 local isolates $B$. thuringiensis, there were 15 isolates could cause the mortality of $>50 \%$ of the larvae of C. binotalis, 20 isolates toward lavae of $P$. xylostella and 12 isolates toward larvae of $S$. litura. The isolates, which could potentially be selected based on the pathogenicity, the candidates will then be developed into a biopesticide for pests control of Crocidolomia binotalis, Plutella xylostella and Spodoptera litura on vegetable crops.
\end{abstract}

Keywords: biopesticide, entomopathogenic bacteria, vegetable plants

\begin{abstract}
ABSTRAK
Upaya pemanfaatan bakteri entomopatogenik sebagai insektisida masih terus dikembangkan. Salah satu patogen yang berpotensi untuk dikembangkan sebagai sumber insektisida adalah bakteri Bacillus spp. Penelitian bertujuan untuk mengetahui tingkat patogenisitas, spektrum patogensisitas dan mendapatkan isolat yang memiliki virulensi yang tinggi terhadap hama tanaman sayuran untuk dijadikan sebagai kandidat biopestisida. Pengujian daya bunuh isolat Bacillus thuringiensis terhadap larva uji Crocidolomia binotalis, Plutella xylostella dan Spodoptera litura dilakukan dengan Metode Ohba dan Aizawa. Hasil penelitian menunjukkan bahwa dari 21 isolat $B$. thuringiensis lokal terdapat 15 isolat yang dapat menyebabkan mortalitas $>50 \%$ terhadap larva $C$. binotalis, 20 isolat terhadap larva $P$. xylostella dan 12 isolat terhadap larva $S$. litura. Isolat yang berpotensi selanjutnya akan diseleksi berdasarkan patogenisitasnya kemudian akan dikembangkan menjadi kandidat biopestisida untuk mengendalikan hama Crocidolomia binotalis, Plutella xylostella dan Spodoptera litura pada tanaman sayuran.

Kata kunci : biopestisida, bakteri entomopatogenik, tanaman sayuran
\end{abstract}




\section{PENDAHULUAN}

Tanaman sayuran merupakan komoditi perdagangan penting di Provinsi Sulawesi Utara, oleh sebab itu pemerintah provinsi Sulawesi Utara telah mengeluarkan kebijakan program pembangunan komoditi unggulan pada tanaman sayuran tersebut, sehingga bisa mengelolanya menurut sistem pertanian modern, yakni bercirikan efisiensi dan mampu merespon perubahanperubahan teknologi dan permintaan pasar global (DPTPH, 2011a ; 2011b).

Indonesia merupakan daerah yang memiliki pertanaman sayuran yang cukup besar. Panen tanaman sayuran tahun 2004, 2005 dan 2006 adalah $68,029 \mathrm{Ha}, 57,765 \mathrm{Ha}$ dan $57,732 \mathrm{Ha}$ dan untuk produksinya 21,$1 ; 22,4$; dan 21,96 Ton/Ha (BPS Indonesia, 2008). Hal ini menunjukkan bahwa produksi tanaman sayuran dari tahun ke tahun semakin menurun (Capinera, 2000; Bahagiawati, 2002; Sembel, 2010).

Berbagai usaha telah dilakukan untuk meningkatkan produksi tanaman sayuran antara lain secara intensifikasi maupun ekstensifikasi. Dalam usaha meningkatkan produksi sayuran tentu tidak lepas dari faktor-faktor pembatas yang mempengaruhi kualitas dan kuantitas (Ahmad dan Hussain, 2002). Untung (2006) menyatakan bahwa kerusakan tanaman akibat serangan hama tidak pernah berkurang, malahan semakin meningkat. Kerugian karena hama di Indonesia per tahun diperkirakan $15-20 \%$ dari produksi pertanian total. Petani Sulut sudah terbiasa menggunakan pestisida dalam mengendalikan hama tanaman yang umumnya tidak lagi memperhatikan jenis hama pada waktu penyemprotan. Akibatnya petani cenderung menambah dosis pestisida yang dianjurkan dan interval waktu penyemprotan semakin pendek. Petani sayuran di Kecamatan Tompaso (sentra produksi hortikultura di Kabupaten Minahasa) dan Desa Rurukan (sentra produksi sayuran di Kota Tomohon) dan Desa Modoinding (sentra produksi sayuran) menyemprot sampai 10 kali dalam satu musim tanam. Adanya pengaruh buruk bagi lingkungan dan fenomena resistensi pada serangga hama akibat penggunaan insektisida telah meningkatkan perhatian para ahli terhadap penelitian tentang pemanfaatan patogenpatogen untuk mengendalikan hama-hama tanaman pertanian (Lonc, et.al., 2001; Untung, 2006). Patogen serangga relatif bersifat spesifik dan pengaruhnya seandainya ada jauh lebih kecil dari pada yang ditimbulkan oleh bahan-bahan kimia terhadap lingkungan atau organisme bukan sasaran.

Seperti halnya pengendalian hayati lainnya (parasitoid dan predator), pemanfaatan patogen di lapangan dapat dilakukan dengan cara mengintroduksikan patogen ke dalam populasi hama dengan harapan dapat menekan secara lebih permanen (Sembel 2010). Penggunaan bakteri entomopatogen mempunyai harapan untuk dikembangkan di masa mendatang. Karena mudah dan murah serta pengaplikasiannya yang efektif dan berwawasan lingkungan.

Penelitian ini bertujuan untuk mengetahui tingkat patogenisitas, spektrum patogenisitas dan virulensi yang tingggi dari bakteri entomopatogenik terhadap serangga hama tanaman sayuran untuk dijadikan sebagai kandidat biopestisida.

\section{METODE PENELITIAN}

Penelitian ini dilaksanakan di Laboratorium Hama dan Penyakit Tumbuhan, Fakultas Pertanian Unsrat, Manado. Penelitian berlangsung pada bulan Juni-November 2012.

\section{Uji Patogenisitas Isolat Unggul Bakteri Entomopatogen terhadap Larva-Larva Tanaman Sayuran Penyediaan Kultur Isolat}

Pengujian daya bunuh isolat $B$. thuringiensis terhadap larva $P$. xylostela dilakukan dengan cara pembuatan inokulum berdasarkan metode yang dikemukakan oleh Ohba, et. al., (1981). Masing-masing isolat $B$. thuringiensis diinokulasikan ke dalam Medium NA dan diinkubasikan selama 48 jam. Selanjutnya untuk setiap isolat dipanen dua cawan petri dan disuspensikan ke dalam $5 \mathrm{ml}$ larutan Ringer Steril (1/4 strength). Konsentrasi spora di dalam suspensi ditentukan dengan metode direct count menggunakan Haemocytometer. 
Perhitungan jumlah spora dilakukan dengan mengambil suspensi yang telah diencerkan dengan larutan Ringer 100 kali (10-2). Haemocytometer yang dipakai berukuran luas $0,0025 \mathrm{~mm}^{2}$ dan kedalaman $0,1 \mathrm{~mm}$ sehingga volume tiap petak adalah $0,00025 \mathrm{~mm}^{3}$. Perhitungan spora dilakukan pada lima bidang pandang mikroskop dengan pembesaran 400 kali. Setiap bidang pandang terdiri dari enam belas petak Haemocytometer. Perhitungan jumlah spora tiap $\mathrm{ml}$ dapat dihitung dengan rumus :

$$
X=\frac{n}{0,00025 \mathrm{~mm}^{2}}=\frac{400}{1 \mathrm{~mm}^{3}}
$$

$$
=\frac{4 \times 10^{6} \mathrm{n}}{\mathrm{ml}}
$$

\section{Keterangan :}

$X=$ jumlah spora per mililiter suspensi

$\mathrm{n}=$ jumlah rata-rata spora yang dihitung pada tiap petak

Berdasarkan nilai konsentrasi yang diperoleh lalu dibuat suspensi dengan pengenceran tertentu sehingga memiliki konsentrasi sebesar $1,5 \times 10^{7}$ spora/ml dengan volume sebesar $20 \mathrm{ml}$ untuk masing-masing isolat. Selanjutnya suspensi isolat tersebut digunakan dalam uji daya bunuh.

\section{Perbanyakan Serangga Uji}

Serangga uji diperoleh dengan mengumpulkan larva dari kebun kubis. Larva $C$. binotalis, $P$. xylostella dan S. litura tersebut kemudian dipelihara di laboratorium. Untuk memperoleh larva dalam jumlah yang cukup maka perbanyakan dilakukan dengan menggunakan daun kubis yang masih segar sebagai pakan. Penggantian pakan dilakukan setiap hari sampai larva menjadi pupa. Setelah menjadi pupa lalu pupapupa dimasukkan ke dalam kurungan kasa (35x75 $\mathrm{cm}$ ). Di dalam kurungan telah disiapkan tanaman kubis muda (umur 3-4 minggu) untuk tempat meletakkan telur. Untuk pakan ngengat diberi larutan madu $10 \%$ yang dioleskan pada kapas. Pemberian madu diberikan setiap hari. Setelah ngengat bertelur dan cukup banyak telur yang diletakkan pada tanaman lalu tanaman dipindahkan ke kurungan lain selanjutnya ditunggu hingga telur menetas dan berkembang menjadi larva instar III. Larva tersebut diseleksi untuk mendapatkan larva yang homogen yang akan dipakai sebagai larva uji.

\section{Uji Daya Bunuh dengan Metode Pencelupan Daun (Leaf Dipped Method)}

Perlakuan pengujian daya bunuh isolat bakteri entomopatogen terhadap larva uji dilakukan dengan metode uji pakan dengan Metode Pencelupan Daun menurut Hamilton dan Attia (1977), yaitu dengan menggunakan potongan daun kubis berukuran $5 \mathrm{~cm} \times 5 \mathrm{~cm}$, potongan daun direndam ke dalam $20 \mathrm{ml}$ suspensi $B$. thuringiensis selama 10 menit, kemudian dikering-anginkan. Selanjutnya dimasukkan ke dalam botol jam (diameter $6 \mathrm{~cm}$ ) yang telah disterilkan dan sebelumnya telah diisi dengan larva instar III (tiap botol 1 ekor) yang telah dipuasakan selama 8 jam. Untuk masing-masing isolat digunakan 30 ulangan (botol). Sebagai kontrol digunakan daun yang dicelupkan ke dalam larutan Ringer steril. Gejala sakit dan perilaku larva diamati dalam selang 6 jam, sedangkan kematian larva dihitung setelah 24, 48, 72 dan 96 jam masa inkubasi. Daya bunuh masing-masing isolat dinyatakan dengan persen mortalitas. Nilai uji daya bunuh yang dihitung dengan formula Abbot:

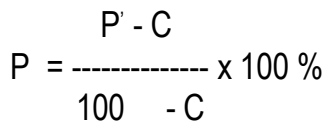

Keterangan :

$\mathrm{P}=$ persentase mortalitas terkoreksi

$\mathrm{P}^{\prime} \quad=$ persentase mortalitas pengamatan

$C=$ persentase mortalitas kontrol

Penyesuaian yang dilakukan dengan formula Abbot ini dilakukan untuk memperkirakan adanya kematian secara alami. Jika kematian kontrol mencapai $20 \%$ maka perlakuan diulang.

\section{HASIL DAN PEMBAHASAN}

\section{Uji Daya Bunuh dengan Metode Pencelupan Daun (Leaf Dipped Method)}

Hasil pengujian 21 isolat bakteri $B$. thuringiensis terhadap larva C. binatalis instar III, 
dari 21 isolat yang diuji, hanya 15 isolat yang dapat menyebabkan mortalitas larva uji lebih dari $50 \%$, sedangkan 6 isolat yang lain, mematikan tidak lebih dari $50 \%$ larva uji, meskipun pengamatan dilakukan sampai hari ke-4 (96 jam) setelah perlakuan (Tabel 1).

Hasil pengujian 21 isolat bakteri $B$. thuringiensis terhadap larva $P$. xylostella instar III, dari 21 isolat yang diuji, ternyata 20 isolat yang dapat menyebabkan kematian lebih besar 50\% dan 1 isolat hanya dapat mematikan kurang dari $50 \%$ (Tabel 2).

Hasil pengujian 21 isolat bakteri $B$. thuringiensis terhadap larva $S$. litura instar III, dari 21 isolat yang diuji, ternyata hanya 12 isolat yang dapat menyebabkan kematian lebih besar 50\% dan 9 isolat lainnya hanya dapat mematikan kurang dari $50 \%$ (Tabel 3).
Dari hasil pengujian semua isolat bakteri B. thuringiensis tersebut terdapat 15 isolat yang dapat mematikan larva uji (C. binotalis, $P$. xylostella dan S. litura) lebih besar dari $50 \%$ setelah 96 jam pada konsentrasi $1,5 \times 10^{7} \mathrm{spora} / \mathrm{ml}$. Gejala yang ditimbulkan sesuai dengan yang dikemukakan oleh Salaki (2010) yaitu serangga uji berubah perilakunya menjadi lamban, berhenti makan, diare dan setelah mati berbau busuk. Larva berubah warna menjadi gelap dan semakin mengecil, khas sebagai bangkai larva yang terserang bakteri. Dengan melihat mortalitas yang diakibatkan oleh isolate patogenik di atas, ternyata dengan konsentrasi $1,5 \times 10^{7} \mathrm{spora} / \mathrm{ml}$ dapat membunuh sampai $100 \%$ dengan waktu \pm 96 jam walaupun kisaran daya bunuh antara isolat sangat bervariasi.

Tabel 1. Mortalitas Larva C. binotalis Instar III yang Diperlakukan dengan Isolat $B$. thuringiensis (Table 1. Mortality Larvae C.binotalis Instar III were Treated with Isolates B. thuringiensis)

\begin{tabular}{cccccc}
\hline No. & Kode Isolat & Mortalitas $(\%)$ & No. & Kode Isolat & Mortalitas $(\%)$ \\
\hline 1. & TPM & 46,7 & 12. & TPTM & 83,3 \\
2. & TYM & 76,7 & 13. & TKBIM & 43,3 \\
3. & TCM & 33,3 & 14. & TKSM & 73,3 \\
4. & TPSM & 56,7 & 15. & TKBM2 & 86,7 \\
5. & TJM & 53,3 & 16. & TDKM & 76,7 \\
6. & TTM & 80,0 & 17. & THMS & 53,3 \\
7. & TPSM & 56,7 & 18. & TRMS & 40,0 \\
8. & TPEM & 43,3 & 19. & TKMS & 56,7 \\
9. & TSKM & 63,3 & 20. & TWT & 73,3 \\
10. & TKBM1 & 56,7 & 21. & TTT & 36,7 \\
11. & TKTM & 76,7 & & & \\
\hline
\end{tabular}

Tabel 2. Mortalitas Larva $P$. xylostella Instar III yang Diperlakukan dengan Isolat $B$. thuringiensis (Table 2. Mortality Larvae P. xylostella Instar III were Treated with Isolates B. thuringiensis)

\begin{tabular}{cccccc}
\hline No. & Kode Isolat & Mortalitas $(\%)$ & No. & Kode Isolat & Mortalitas $(\%)$ \\
\hline 1. & TPM & 53,3 & 12. & TPTM & 100 \\
2. & TYM & 76,7 & 13. & TKBIM & 46,7 \\
3. & TCM & 56,7 & 14. & TKSM & 76,7 \\
4. & TPSM & 60,0 & 15. & TKBM2 & 100 \\
5. & TJM & 56,7 & 16. & TDKM & 73,3 \\
6. & TTM & 83,3 & 17. & THMS & 60,0 \\
7. & TPSM & 60,0 & 18. & TRMS & 56,7 \\
8. & TPEM & 50,0 & 19. & TKMS & 63,3 \\
9. & TSKM & 66,7 & 20. & TWT & 70,0 \\
10. & TKBM1 & 60,0 & 21. & TTT & 50,0 \\
11. & TKTM & 76,7 & & & \\
\hline
\end{tabular}


Tabel 3. Mortalitas Larva S. litura Instar III yang Diperlakukan dengan Isolat $B$. thuringiensis

(Table 3. Mortality Larvae S. litura Instar III were Treated with Isolates B. thuringiensis)

\begin{tabular}{cccccc}
\hline No. & Kode Isolat & Mortalitas $(\%)$ & No. & Kode Isolat & Mortalitas $(\%)$ \\
\hline 1. & TPM & 43,3 & 12. & TPTM & 66,7 \\
2. & TYM & 70,0 & 13. & TKBIM & 40,0 \\
3. & TCM & 43,3 & 14. & TKSM & 63,3 \\
4. & TPSM & 56,7 & 15. & TKBM2 & 76,7 \\
5. & TJM & 46,7 & 16. & TDKM & 66,7 \\
6. & TTM & 76,7 & 17. & THMS & 46,7 \\
7. & TPSM & 53,3 & 18. & TRMS & 43,3 \\
8. & TPEM & 46,7 & 19. & TKMS & 56,7 \\
9. & TSKM & 56,7 & 20. & TWT & 53,3 \\
10. & TKBM1 & 46,7 & 21. & TTT & 46,7 \\
11. & TKTM & 60,0 & & & \\
\hline
\end{tabular}

Untuk mengetahui secara lebih jelas mengenai patogenisitas isolat potensial tersebut maka perlu dilakukan pengujian secara kuantitatif dengan konsentrasi spora yang bervariasi dari yang rendah sampai pada yang lebih tinggi sehingga dapat ditentukan nilai $\mathrm{LC}_{50}$ dan $\mathrm{LT}_{50}$ masing-masing isolat. Isolat yang diuji daya bunuhnya di antara 15 isolat potensial dipilih berdasarkan kemampuan menimbulkan mortalitas lebih besar $50 \%$ pada pengamatan jam ke-24.

\section{Gejala Larva Terinfeksi B. thuringiensis}

Hasil pengamatan menunjukkan bahwa aktivitas larva mulai terganggu pada hari pertama setelah perlakuan. Gejala yang terlihat pada larva yang terinfeksi $B$. thuringiensis yaitu larva yang selalu bergerak tetapi lamban, kemudian menjadi sangat lamban dan sama sekali tidak makan. Larva yang telah sangat lamban kadang-kadang mengeluarkan cairan dari mulut dan anus (diare). Larva yang menjadi diam ataupun yang baru mati mengalami gejala edema (Lee, et al., 2003; Trizelia, 2003; Suharto, 2004; Khetan, 2001; Salaki, et al., 2007; 2009a; 2009b; 2009c; 2010a; 2010b; 2011a; 2011b), kemudian berwarna gelap. Bangkai tersebut berbau busuk, dan pada hari berikutnya semakin mengecil, khas sebagai bangkai larva yang terserang bakteri. Gejala ini terlihat pada larva yang terinfeksi $B$. thuringiensis dari setiap perlakuan konsentrasi. Gejala serta perubahan yang terjadi pada larva setelah aplikasi menunjukkan perbeda- an dengan larva yang sehat. Ada larva yang terinfeksi dan sempat membentuk benang-benang yang menutupi dirinya tetapi tidak berhasil membentuk pupa, namun ada juga larva yang berhasil menjadi pupa tetapi pupa tersebut tidak normal yaitu warnanya hitam dan agak kisut (tubuhnya mengecil) dan yang berhasil menjadi ngengat, sayapnya tidak membuka tetapi melipat ke bagian toraks.

\section{KESIMPULAN}

Pengujian daya bunuh 21 isolat $B$. thuringiensis terhadap hama $C$. binotalis, $P$. xylostella dan $S$. litura yang dapat menyebabkan mortalitas larva uji lebih dari 50\% berturut-turut 15 isolat, 20 isolat dan 12 isolat.

B. thuringiensis dapat menyebabkan mortalitas yang cukup tinggi pada larva $C$. binotalis, $P$. xylostella dan $S$. litura sehingga bakteri ini dapat digunakan sebagai kandidat biopestisida yang ramah lingkungan.

\section{UCAPAN TERIMA KASIH}

Terima kasih kami sampaikan kepada Direktorat Jendral Pendidikan Tinggi Kementerian Pendidikan dan Kebudayaan lewat penelitian Prioritas Nasional Masterplan Percepatan dan Perluasan Pembangunan Ekonomi Indonesia, yang telah mendanai penelitian ini. 


\section{DAFTAR PUSTAKA}

Ahmad, S. and Z. Hussain. 2002. Entomophatogenic Nematodes Associated with Soil Types and Vegetation Cover in Potwwar Region of Pakistan. Pakistan Journal of Biological Sciences. 5(6):640642.

Badan Pusat Statistik Indonesia (BPS Indonesia). 2008. Produksi Tanaman Sayuran. Badan Pusat Statistik Indonesia. http://www.bps.go.id/sector/agri/horti/index .html\#methodologies. Diakses tanggal 14 Nopember 2008.

Bahagiawati, A. 2002. Penggunaan Bacillus thuringiensis sebagai Bioinsektisida. Buletin AgroBio. 5(1):21-28.

Capinera, J.L. 2000. Plutella xylostella Linn. http://creatures.ifas.ufl.edu/veg/leaf/diamo ndbackpupa.html. Diakses tanggal 26 Nopember 2007.

[DPTPH] Dinas Pertanian Tanaman Pangan dan Hortikultura. 2011a. Laporan Pelaksanaan Data Base Hortikultura. Bagian Proyek Pengembangan Agribisnis Hortikultura dan Aneka Tanaman Sulawesi Utara.

Dinas Pertanian Tanaman Pangan dan Hortikultura (DPTPH). 2011b. Program Pengembangan Komoditi Unggulan Tanaman Pangan dan Hortikultura T.A. 2001-2004 Di Propinsi Sulawesi Utara.

Hamilton, J.T. and F.J. Attia. 1977. Effects of Mixtures of Bacillus thuringiensis and Pesticide on Plutella xylostella and the parasite Thyracella collaris. Journal Economic Entomology. 70:146-148.

Khetan, S.K. 2001. Microbial Pest Control. Marcel Dekker, Inc. USA.

Lee, D.H., Cha I.H., Woo D.S., and Ohba M. 2003. Microbial Ecology of Bacillus thuringiensis Fecal Populations Recovered from Wildlife in Korea. Canadian Journal of Microbiology. 49(7):465-471.

Lonc, E., W. Doroszkiewicz, M.J. Klowden, K. Rydnanicz, and A. Galgan. 2001. Entomophatogenic Activities of Enviromental Isolates of Bacillus thuringiensis Against Dipteran Larvae. Journal of Vector Ecology. 26(1):15-20.

Ohba, M., K. Ono, K. Aizawa, and S. Iwanami. 1981. Two New Subspecies of Bacillus thuringiensis Isolated in Japan. $B$. thuringiensis subspecies kumamotoensis (serotype 18) and B. thuringiensis subspecies tochigiensis (Serotype 19). Journal of Invertebrate Pathology. 38:184190.

Salaki, Ch.L., G. Manengkey, dan D. Tarore. 2007. Penyebaran, Kepadatan Populasi dan Kemungkinan Aplikasi Bacillus thuringiensis Isolat Lokal dalam Pengendalian Vektor Penyakit Demam Berdarah di Kota Manado. Laporan Hasil Penelitian Fundamental.

Salaki, Ch.L., J. Situmorang, dan L. Sembiring. 2009a. Isolasi dan Karakterisasi Bakteri Indigenous Indonesia (Bacillus thuringiensis) yang Berpotensi sebagai Agensia Pengendalian Hayati terhadap Serangga Hama Kubis (Crocidolomia binotalis). Pros.Seminar Nasional Basic Science VI Fakultas MIPA Universitas Brawidjaya, Malang.

Salaki, Ch.L. 2009b. Uji Patogenisitas Isolat Bakteri Indigenous (Bacillus thuringiensis) Terhadap Serangga Hama Kubis (Crocidolomia binotalis). Jurnal BIOTA Vol.14(3) : hal 192-197.

Salaki, Ch.L. 2009c. Analisis Diversitas Isolate (Bacillus thuringiensis) Indigenous Indonesia yang Patogenik Terhadap Crocidolomia binotalis dengan Pendekatan Sistemik Numeric. Jurnal BIOTA Vol.14(3): hal 192-197.

Salaki, Ch.L. 2010a. Keanekaragaman Genetik Isolat Bacillus thuringiensis Berliner Endogen Indonesia Sebagai Agensia Pengendali Hayati Hama Crocidolomia binotalis Zell. (Lepidoptera : Pyralidae) Pada Tanaman Kubis. Disertasi Doktor UGM Yogyakarta.

Salaki, Ch.L. 2010b. Isolasi dan Karakterisasi Bakteri Indigenous Indonesia (Bacillus thuringiensis) yang Berpotensi Sebagai 
Agensia Pengendalian Hayati terhadap Serangga Hama Kubis (Crocidolomia binotalis). Jurnal AGRIVITA Vol. 31(2) : hal 174-181.

Salaki, Ch.L. 2011a. Isolasi dan Karakterisasi Bakteri Indigenous (Bacillus cereus Frank.) Sebagai Agensia Pengendali Hayati Hama Kubis. Jurnal Eugenia Vol.17(1): hal 10-15.

Salaki, Ch.L. 2011b. Aplikasi Metode ARDRA dalam Identifikasi Isolat Bacillus thuringiensis Endogenik Sebagai Pengendali Hama Kubis Crocidolomia binotalis. Jurnal Eugenia Vol. 17 (2).
Sembel, D.T. 2010. Pengendalian Hayati. Fakultas Pertanian Unsrat Manado. Andi Offset Yogyakarta.

Suharto. 2004. Pathogenicity of Beauveria bassiana Isolates on Plutella xylostella. Jurnal Perlindungan Tanaman Indonesia. 10 (2) : 8-12.

Trizelia. 2003. Pemanfaatan Bacillus thuringiensis untuk Pengendalian Hama Crocidolomia binotalis. Kumpulan Makalah Entomologi. Jakarta.

Untung K. 2006. Pengantar Pengelolaan Hama Terpadu. Edisi Kedua. Fakultas Pertanian UGM, Gadjah Mada University Press. 